\title{
Where is the violence in identity-related violence? The generative potentiality of violence in ethno-religious conflict and mass purging in Indonesia
}

\section{Geger Riyanto}

University of Heidelberg, Institut für Ethnologie, Germany.

Email:geger255@gmail.com

\begin{abstract}
This article argues that we have to address the generative potentiality of violence in drawing a rigorous depiction of identity-related violence. Works on identityrelated violence often explain the violence as culminating from the perpetrators' sense of identity. Even though to some extent such an explanation sheds light on the perpetrators' motivation, it is prone to reducing the actuality of violence to a mere epiphenomenon. In actual circumstances of conflict and purging, the frightening and engrossing horror of violence convincingly imposes the antagonistic discursive boundary of self and other on the involved subject's senses. As an efficacious embodiment of identity, violence also entails the subjects perpetually performing it in a way that reinforces the facticity of the fictive categories of identity and eventually escalates the violence. This article makes its case through an examination of two incidents of massive violence in Indonesia: the 1966-69 communists purging and the 1999-2002 ethno-religious conflict in Maluku.
\end{abstract}

Keywords: Identity-related Violence, Identity, Ethno-Religious Conflict, Mass Purging, Indonesia. 


\section{Introduction}

There is a commonly accepted notion that the way subjects conceptualize their selves potentially prompts them to inflict unimaginable suffering on the other. In his acclaimed essay, In the name of identity, Maalouf (2001) stated his belief that "men of all countries, of all conditions and faiths can so easily be transformed into butchers ... because the "tribal" concept of identity still prevalent all over the world facilitates such distortion' (2001). Maalouf, an acknowledged writer, certainly is not the only one to endorse such a notion. The most captivating form of violence today is that which expressively delivers a religious message, and we, as shown in popular opinion, mostly interpret it is as an action driven by the perpetrators' belief of belonging in a different community from the other. These subjects, as we see it, are being exposed to radical ideology through which they falsely understand that their purpose in life is to wage war against people they consider to be antagonistically different from themselves.

Scholarly discourses related to this issue are ample and multifarious. A good number of respectable literatures maintain that identity has considerable impact in compelling violence (Deng, 1995; Kapferer, 1988; Ross, 2002; Wellman Jr. \& Tokuno, 2004; Volkan, 2006). Amartya Sen, a well-known economist who has consistently conveyed his concern with the fatal potentiality of identity, for instance, noted that '[i]t is the symbiotic relation between the two contrary faces - with love for members and non-love for non-members that makes identity such a potent force in the world with great creative powers as well as massively destructive potentials' (Sen, 2008). Another writing that we may call to our attention is Juergensmeyer's Terror in the mind of God (2003). Why do people possess the motivation to carry out religious violence even though oftentimes the result is considered senseless and immoral? Juergensmeyer's extensive investigation points out that such motivation is due to the sense of a cosmic war instilled by religious doctrines of the perpetrator's community. Violence turns into a sensible act as it is being interpreted as a struggle for defending one's basic identity.

This paper calls for the need to critically appraise this casual understanding of identity-related violence. Evidence that will be presented suggests thinking of violence as simply the repercussion of a distinct sense of selfhood remarkably overlooks its actual relationship with identity. Although it is not mistaken to say that the identification of self as part of a bounded moral community has enabled people to act disturbingly viciously to the other, in actual circumstances 
of intergroup conflict, purging, and killing, the sense of identity is often evoked following people's entanglement in the cycle of violence. Contrary to our imagination about the perpetrators of identity-related violence, these people are not carrying out their act simply as a result of being instructed by a certain value, cosmological claim, or sense of selfhood that has detached their moral and social sensibility from other people. It is the striking spectacle of human suffering and mortality-or as Reemtsma (2012) said, the reduction to a mere body-that entices them to participate in the violence as well as prompts them to assume an antagonistic identity.

It will be argued in this paper that, as much as it is discursive in nature, the boundary of the self and the other that establishes the identity of the subjects also intricately pertains to the performance and the interplay of violence. Instead of simply stemming from the act of identity, the actuality of the violence fosters the antagonistic self-representation as well. The actuality of the violence 'acts toward the idea' by erecting tangible and sensually appealing signs of identity. The horror of the violence-the representation of a savage ferocity that is capable of evoking a compelling feeling among its perceiversmakes it possible for the abstract boundary to be experienced 'objectively'. A group's fear, hatred, and grudge against another group that has brutalized it present the subject who shares common attributes with the former group it, for instance, with a convincing sense of being ontologically different from the latter group. The certainty of violence as an act of harming the other (see Riches, 1986) oftentimes erects violence as an expression of identity, allowing it to be reproduced rapidly.

I will elaborate my argument-that the materiality of identity-related violence perpetuates the antagonistic identity, which, eventually, imposes the boundary that encourages violence in return-by examining two cases of violence in Indonesia: (1) the 1966-69 communists purging; and (2) the 1999. 2002 ethno-religious conflict in Maluku. I will employ data from previous studies, reports, and investigations that provide a depiction of the violence, especially how it was reproduced after semiotic associations between the violence and the groups involved in it were erected. My inquiry will allow us to see the intertwined nature of violence and identity; action and abstract boundary; and materiality and discursive arrangement that, despite being the chief issue in social theory debates for some time (Henare, Holbraad \& Wastell, 2007; Miller, 2005; Sahlins, 1985, 1991; Sewell, 2005), has been largely overlooked in attempts to theorize identity-related violence. Social studies of violence tend 
to overlook the performative dimension of violence by explaining it as the repercussion of the abstract or as a macro arrangement, such as morality, statebuilding process, or struggle for resources (Hartmann, 2017). Yet, the notion that has accrued, that violence is senseless, non-referential, transformative, inconceivable, or poetic (Argenti \& Schramm, 2010; Bloch, 1992; Dodd, 2009; Scarry, 1985; Whitehead, 2005) hints that the act cannot be casually reduced as an epiphenomenon of more fundamental social or cultural processes. The rapidly spreading identity-related violence involves a complex dynamic which entails not only the abstract notion of identity. Rather, the imagined boundary must be constantly instantiated through social subjects' acts of signification. It is through the interplay of violence, I argue, that the antagonistic idea of self and other comes to be presented as a socially incontestable fact.

My inspiration for my theoretical vista comes largely from my reading of Elaine Scarry's (1985) notable work on pain. According to Scarry, bodily injuries and their representations inflict on the senses an engrossing feeling of being here and now. This feeling evokes a strong sense of immediacy that potentially disturbs one's already established and firm understanding of the world. As a pure experience of violence is impossible (Staudigl, 2014), however, the 'negative certainty' (Marion, 2010) of violence instead serves to impose a feeling of facticity on subjects' senses regarding the semiotic associations they abstract from the violent event. In cases where its occurrence is associated with identity, then, violence serves to bring antagonistic fictive categories of self and other to their full actual presence. The 'frightening power of substantiation' of decimated bodies acts as reality-confirming forces (Scarry, 1985) to the antagonistic identity of both the perpetrator and the victim involved in the violent circumstances. It designates the collectively associated with the perpetrator as an undeniable threat to the victim's existence, while urging victims to act as a collectively to defend themselves and counter the violence which, eventually, incites them to perpetually perform their identity through violence.

\section{Literature Review}

\section{The Emergence and Performance of anti-communist Identity}

In the middle of the 1960s, following a failed coup attempt claimed to be carried out by the Indonesian Communist Party (Partai Komunis Indonesia/ PKI), the biggest purging in Indonesian history broke out throughout the country. Communist party members, their affiliates, and anyone alleged to be 
a sympathizer were widely and openly hunted down. It is estimated that from 200,000 to 800,000 people lost their lives as a result of the purging. Millions were imprisoned without trial and stripped of their rights as citizens (Cribb, 2001). For some people, the grand scale of the violence was not unexpected, as they believed it to be the result of Cold War strife among global powers and dissension among notable political factions of the country (Ling, 2011). The military, the biggest political rival of the Indonesian Communist Party, had a crucial role in orchestrating the purging as well (Melvin, 2014; Robinson, 2017), while in many localities the struggle over strategic positions and land ownership had worsened the relationship between communists and influential local actors who later had a principal role in mounting the purging of the communists (Robinson, 2017).

However, the notion that the purging stemmed from a struggle over resources and power is not a sound explanation of how the violence came to be practiced by common people. By encouraging the people to crush the communist party while arming and assembling groups of civilian vigilantes to exterminate their greatest threat (Hasworo, 2004), the military, through the Army Paracommando Regiment, was openly responsible for setting the wave of violence into motion. Yet, in a number of locales, a remarkably large number of civilians actively participated. They demonstrated a strong emotional involvement in the purging which resulted in the staggering number of casualties. In the province of East Java, one of the places where the casualty number was substantially higher than many other locales, people frequently set siege to a village in order to capture communist party members. In order to do so, one account described, they would need as many as 3,000 people (Rochijat, 1985). In Aceh, a province where the casualty number was also relatively high considering the miniscule presence of the communist party there, assembled vigilante student groups even insisted on continuing to escalate the violence after the military acted to end the purging (Melvin, 2015). In a number of other places, rather than being mobilized by the military, it was the civilians who took the initiative to cooperate with it, in order to act against the communist party in their area (Young, 1990).

The question, then, is what encouraged common people to involve themselves in the purging? In seeking an answer, we may find that the discourse of identity appears to have played a pivotal role. It appears typical that the violence toward the communists was propelled by Islamic organizations. They considered communism to be incompatible with Islam and attributed atheism 
to the communists in their attempt to rally the people against them (Young, 1990). Muslim organizations in the province of East Java assumed that it was their obligation as Muslim to crush the PKI for their transgressions. In Surabaya, the capital city of the province, a branch of a major Islamic party, Nadhlatul Ulama, decreed the eradication of PKI as a religious duty. Ansor, a prominent Muslim youth organization, held a 'Vigilance Rally of Godly People' in towns, and they planned that during the rally they would attack the communist party headquarters and members. However, even in locales where Islamic organizations were conspicuously responsible for galvanizing the widespread purging, the involvement of common people in the violence was never simply the result of how the perpetrators positioned themselves and the other on their religious horizons, especially since in Indonesia the communists had not always been imagined as Islam's existential enemy (McVey, 2006 [1965]). The antagonistic demarcation between Islam and PKI was at some point invented and imposed, and images of violence were crucial in cultivating the imagined antagonism between the two groups.

What I want to call to our attention is that most attempts to mobilize the Muslims comprised reminding people of the past perpetration of violence conducted by the PKI. The depiction that PKI assaulted Islamic religious leaders, attacked Islamic schools, and defiled mosques or the Koran was persistently present in the attempt to rally Muslims against the communists. Representations of violence conveyed that the pious Muslims were being abused by the atheist PKI, and it was the Muslims' religious obligation to defend their people against PKI's cruelty. The representation of one particular past event has been argued to have played an essential role in preparing the ground for the widespread communist purging (McGregor, 2009). This event was the killing of teachers, officials, and religious leaders affiliated with the Islamic party Masyumi in the city of Madiun at 1948. It happened while the city was being taken over by a leftwing opposition group that was discontent with the new cabinet and its policies. Immediately following the 1965 coup, the Madiun event was repeatedly recalled as evidence of the wickedness of the communists. It served to substantiate that the 1965 coup-although nothing could be immediately known regarding who were its initiators-was another scheme of the communists to backstab the Muslims. Religious leaders wrote openly in the media that the Muslims had to act swiftly before they were annihilated by the PKI. In a leaflet circulated in East Java that called for Muslim participation in the rally against the PKI, it was written that 'thousands of Muslims were murdered by the other side [in 
the Madiun Incident in 1948]' (Young, 1990). Years later, interviews conducted by McGregor (2009) with prominent Nadhlatul Ulama figures found that the Madiun killings assured them that they had to decimate the communists if they did not want to be decimated themselves.

We may notice as well that, in representing the violence, the involved Muslim organizations and figures indeed tried to frame it in accordance with their narrative. The interpretations regarding who was responsible in setting the Madiun affair into motion differed among different collectivities, especially the parties that had their political interest at stake. This affirms that the actuality of the violence was unavoidably encompassed by the subject's horizon of thinking and self-representation. Nevertheless, we cannot exempt the fact that the sensually engrossing representation of abused and slaughtered bodies was, for the most part, not absent from attempts to incite people's participation in the communists purging. People were compelled to perform violence on the communists as they needed to display their piety as a Muslim. It was, however, the material traces of persisting past violence that prompted them to convincingly project the communists as their antagonistic other and, consequently, that allowed them to perform themselves as Muslims by purging their religious enemy. In this respect, the recurring presentation of the past negativity created a socially incontestable demarcation between Muslims and communists, and with this demarcation, the threatened self and existential threat could be actualized.

Of course, given the massive reach of the communists purging, not every common person who was compelled to participate in the purging acted to reciprocate the communists' past violence or to defend the religious community from decimation. Nonetheless, even in other circumstances where the purging was not enacted as a moral calling, the actuality of violence still played an important part in actualizing the boundary of the self and the other which eventually obliged people to participate in the violence toward the communists. After a series of intricate affairs following the coup, a master narrative that the communist party was a traitor that attempted to take over power through any means possible was successfully erected. At this point, violence, as a highly visible act with an unmistakable intention of hurting the other (Riches, 1986), became an expression of allegiance to the nation, provided it targeted the PKI. Despite holding no personal or collective resentment toward the communists, anyone who did not want to be alleged a PKI sympathizer had to openly display the expression of violence toward the group that was successfully being portrayed 
as a threat to the country.

The Ibanese tribe that lived in the inland of Sabah and Sarawak, for instance, had to purge people from their own kin who were members of Paraku, a wing of the communist party in the region (Pirous, 2004). Consequently, the instruction to kill any Paraku they saw often struck the Ibanese paramilitary squad assembled by the military with a sense of moral confusion. Before executing a Paraku soldier, an ex-Ibanese paramilitary reported, he would ask the man more than twice whether he was really a member of Paraku. In circumstances where he had to execute his own people, this Ibanese had to convince himself that he got a full sense of his action. Conversely, there were times when Ibanese were found sheltering and feeding the fleeing Paraku. These protectors would then be publicly tortured by the military for their action. Some had their longhouses napalmed and their livestock killed. One of the Ibanese who was punished at the time could not blame anyone but himself for the punishment. 'We were stupid... stupid!' he said. 'The army wasn't wrong because in fact we had made friends with the enemy'.

The kind of ill treatment that befell the Ibanese was ubiquitous at the time. There are reports that the Army Paracommando Regiment used intimidation and coercion as they went to cities and villages and instructed civilians to crush the communists. (Hearman, 2017; Liem, 2004). While such reports affirm the thorough role of the military in initiating the purging, people's participation was also obliged due to the effectiveness of violence in signifying the perpetrators attempt to negate its target and, eventually, their allegiance to the legitimate regime which had established the communists as their existential threat. Even without direct intervention of the military, at a number of locales, violence toward the communists was enacted because it brought social affirmation to the people who were capable of displaying it. High school students in Kediri often voluntarily inspected places in order to round up any communists they found and turn them over to executioners, even though these youths were not in any way related to the political affairs that led to the purging (Rochijat, 1985). Heads of village exaggerated the number of communists killed in their village as they thought they would be rewarded if they mobilized their villagers against the communists (Cribb, 1990). And, of course, the Islamic organizations rallied against the communists were keen on taking action because of the effectiveness of violence in displaying their group devotion.

Hence, while the antagonistic boundary of self and other was pervading social life everywhere, it is clear that the violence was enacted for its potentiality in 
conveying the subjects' self-representation. Indeed, the violence was performed in accordance with the logic of identity. However, it was enacted not only to articulate that logic but also because the form of identity that emerged in this circumstance entailed the efficacious embodiment of violence. It was through the enthralling spectacle of violence that the subjects involved in the violence were able to present themselves explicitly as anti-communist individuals and avoid the dire consequences of being alleged a sympathizer or receiving an exalted affirmation from their own collectively. Being the materiality of anticommunist identity, then, violence was established as the socially preferred and obliged action which led to the reproduction of both the antagonistic boundary and violence toward the communists.

\section{Results and Discussion}

\section{The Instantiation and Intensification of Antagonistic Boundary in Maluku}

Now I wish to further exemplify my argument by putting forward another notable case of wide scale violence in Indonesia which, in contrast to the communists purging, occurred rather recently. The violence, often referred to as the Maluku sectarian conflict, took place from 1999 to 2002. In popular accounts, the conflict is viewed as ethno-religious strife in which the Christian natives of Maluku clashed with Muslim migrants, resulting in a wave of violence in all over Maluku. It is estimated that more than 5,000 people died during the conflict and hundreds of thousands were displaced. Although the conflict ended with the signing of the Malino agreement, the city of Ambon remains segregated along ethno-religious lines to this day. Minor clashes continue to recur, indicating that religious groups still have a problem in co-existing with communities of a different religion (Ansori et all., 2014).

The eruption of the conflict is often seen as originating from a dispute over economic and political resources among local and national elites, while also being fueled by the sudden influx of Muslim migrants from Sulawesi to the Christian dominated area of Maluku (Human Rights Watch, 1998). The struggle over bureaucratic position is also suggested to have exerted a pivotal role in fostering the sense of antagonism (Klinken, 2007). The appointment of a Muslim governor and the replacement of many important Christian officials in a province where the economy depended heavily on governmentbased projects stirred a sense of anxiety among the Christian population that 
considered itself the native people of the land. As resentment toward the migrants built up, Christian religious institutions and symbols played the role of attributing the Muslim group as their existential antagonist. The perception that the Muslims were conspiring to take over the land of Ambon spread rapidly due to dissemination through churches (Braithwaite, 2013). Eventually, when a clash which had nothing to do with religious symbols occurred, it was quickly transformed into religious friction because of the already established association of those involved with a certain religion. This association led to the involvement of people who initially were unrelated to the conflict and, later, it bolstered the escalation of the conflict to an unprecedented scale (Duncan, 2014; Wilson, 2011).

Due to its multifaceted characteristic, it should be expected that Maluku ethno-religious conflict turned into a fertile ground for debates between scholars who argued it was caused and sustained by an 'ideological' factor and those who attribute its root to a 'structural' factor (Duncan, 2014). I suspect, however, that this debate is another attestation of our inclination to overlook the actual performance in examining cases of violence. When we try to make sense of how it actually escalated, it will be evident that the frightening performances of violence were constitutive in producing, imposing, and sustaining the antagonistic boundary between the conflicting groups, as much as the notion of identity produced, imposed, and sustained the actors' destructive action. As much as religious symbols' playing an important role in urging people to be involved in the conflict, we also encounter indications of people immediately affiliating themselves with a certain religious community when they see violence brutally perpetrated by the other group. Religious self-identification often culminated following the act of violence that signified the perpetrator as an undeniable existential threat and one's self as the victim.

Cases like that of Hamid (Human Rights Watch, 1998), for instance, were not uncommon during the days of the conflict. Hamid, a Muslim boy, saw his family being violently killed by a Christian mob right in front of him. He almost became a victim himself but was able to flee from the mob after saying the he was a Christian. Hamid then immediately grabbed a container of gasoline. He intended to burn the nearest church he could find. This example suggests that in this conflict a firm identification of the self and the other was instilled through an exceptionally disturbing experience. The pain and distress incited by the event erected the fictive category of identity into a compelling and objective reality. Of course, in order for people to be able to associate the 
perpetrators with a certain religious community, a discursive boundary had to have been established previously. The victims of the violence had to already imagine themselves belonging to a religious community and acknowledge its symbols prior to the event. However, we should not overlook the practical effect the violence had in the rapid reproduction of identity. During the conflict, all of a sudden, the antagonistic boundary thoroughly pervaded every facet of Maluku social life. The identity, which did not necessarily have to be performed all of the time prior to the conflict, emerged as something that was perpetually articulated through people's everyday actions. This constant articulation occurred as violence became not only the materialization of antagonistic identity but also its highly enticing reification which forced people to accept and act on its facticity that threatened their very existence and incited their urge to reciprocate through counter-violence (see Girard, 1977; Levi-Strauss, 1969; Sahlins, 1972).

The chronology of the escalation of the Maluku conflict (Human Rights Watch, 1998) provides a straightforward depiction of this correspondence between identity and violence. The conflict started on 19 January 1999 as nothing more than a minor dispute between a Christian public transport driver and two Bugis Muslims in the village of Batu Merah. Later in the afternoon, a Muslim mob marched toward Batu Merah. The crowd, composed of people from outside Batu Merah, torched houses and the market in the village. The crowd was apparently provoked by a false rumor that the mosque at Batu Merah had been burned by the Christians. Not much later, a church was burned at Kampong Silale and Waihong along with the local villagers' houses. As accounts of the attacks spread rapidly, Christians from several areas started to take countermeasures as well as tried to get revenge. On the night of 19 January, a large and well-organized mob of Christians attacked Kampung Paradeys. They carried pipes, knives, and machetes, and they smashed houses while shouting obscenities against Islam and claiming that their church had been burned. They targeted some ethnic groups in particular and kept crying 'kill' and 'burn'. There were widespread burnings and killings as Christian attacks occurred in many other places during the same time that Muslim mobs continued to attack Christian villages. By 20 January, all major markets in Ambon city had been burned down by Christian forces. Common people from various villages were already affiliating themselves with a certain religion and were ready to be mobilized anytime they sensed they would have to defend their religion or avenge their people. In some places, religious symbols glaringly accompanied 
the violence. The Muslim crowd was often witnessed shouting 'Allahu Akbar' (God is great) while attacking their enemy, and the Christians were seen singing a song about how they will win the war with the blood of Jesus.

In a mere few days after the conflict started, the violence was already spreading to other islands in Maluku. The spreading occurred as people in many places were provoked by the news that members of their religion were being slaughtered. They became engulfed with fear toward people from the other religion in their own locales (see also Winn, 2000). In April 2000, Laskar Jihad, an anti-Christian militia group, assembled in Java and rallied thousands of militias to Ambon where their presence lent to the dramatic escalation of the conflict. As the proponents of the movement said, the intention to carry out jihad arose as they perceived that the Muslims, the armed forces, and the president, which they thought to be the three pillars of the state, had been toppled by inter-religious violence (Hasan, 2006).

We could convincingly argue that this rapid escalation of the Maluku conflict would not have occurred had the process Tambiah (1996) termed focalization and Tran's valuation never taken place. As the conflict revolved around religious symbols and boundaries, semiotic associations that emerged during the initial phase of the conflicts were immediately dissociated from their actual context of occurrence. Rather than seeing the earlier clashes as an ordinary intergroup dispute, people perceived them as a sign of perpetration of harm against their religion and, due to this belief, they felt a compelling sensation of anxiety, distress, and the urge to perpetrate counter-violence on people from the other religion. This, eventually, led to the widespread escalation of the conflict and suggests to us that religious self-identification had a profound role in setting the series of events in motion. Nevertheless, the antagonistic identity was being instantiated effectively and intensively through the frightening performance of violence. The fear of Muslim migrants had already been flourishing for some time. The sudden outbreak of violence was the necessary event that presented to the people a striking confirmation regarding their imagination. The chronology of the conflict exemplifies how violence performed by a group of people carrying religious attributes forces those designated as its target also to imagine themselves as a religious community while trying to conduct counter-violence as such. The violence evoked an undebatable discursive circumstance in which all subjects were required to assume a religious identity in order to meaningfully respond to the other.

We also have to consider the fact that religious symbols were effective 
when they were the subject of desecration and destruction. The horrendous death of people from the same religion, the burning of religious buildings, and the defilement of holy books were the events that particularly inflicted the sense of fear, resentment, and grudge on the boundary and eventually allowed the abstract conception of antagonistic identity to turn into a powerful and actively performed actuality. The Laskar Jihad militia, for instance, was composed mainly of youth who never grasped the Maluku conflict as a struggle between the native and the migrant. Instead, they perceived it as a religious war between their Muslim brothers and the Christians. What, then, prompted them to volunteer to carry out jihad in Ambon? For most of them, it was the horrific images and stories that narrated a slaughter of Muslims in Maluku-the bodily evidence of perpetration and killing (see e.g. Bräuchler, 2004). What being experienced by the Laskar Jihad militia, of course, was not uncharacteristic at the time. A former teenaged militia admitted that his involvement in the conflict had been prompted by the death of two of his best friends (Bjorkhagen, 2013). Meanwhile, a survey conducted with 50 Christian ex-fighters in Ambon found that their primary motivations for engaging in the warfare were as follows: (1) to defend religion/Christianity and the Christian community (90.2 percent); (2) Jesus Christ had been humiliated (80.4 percent); (3) churches were destroyed (80.2 percent); (4) the Bible was burnt (70.5 percent); (5) Christian pastors/ministers had been murdered (64.7 percent); and (6) to guard Christian territory (82.4 percent) (Al Qurtuby, 2015).

Hence, not unlike the case of communists purging, it was through the horror of violence that differences in social subjects' attributes were erected into a tangible identity that prompted them participants in the violence to continuously perform it. The rapidly spiralling ethno-religious conflict in Maluku presents to us a case of violence as generative as much as it is generated by the subject's self-representation. If we were to seek further substantiation from other cases of identity-related violence about this potentiality of violence, meaningful comparison would be found in a number of insightful studies (Bakker, 2015; Kivimäki, 2013; Peluso, 2006). Just as Kenneth George (1996) remarked in respect to the headhunting practices of the Ada Mappurondo people in the highland of Sulawesi, violence is a 'declaration of social difference'. Regardless, the idea that this paper intends to present had already been thoroughly explicated through two cases above.

The intertwining of violence and identity, which evidently propelled the escalation of the communists purging and ethno-religious conflict in Maluku, 
shows that we may need to seriously scrutinize our theoretical understandings of identity-related violence. Despite apparently being enacted as an expression of identity, violence cannot be attributed as merely its epiphenomenon. Its occurrence and imprint on social subjects' senses is significant not only in sustaining the boundary but also in prompting the boundary to be rapidly spread. The violence compels the subject to act in a way that reinforces and reproduces the antagonistic identity itself. What becomes evident in the examination in this paper is that in a rigorous explanation of the fabrication of antagonistic identity in violent circumstances, we must account for the potentiality of the violence itself.

The difficulty for some time in incorporating the conspicuous effect of violence in inquiries into identity-related violence probably issues from the bifurcation between the social and the material. Since Durkheim, who was arguably inspired by Kant's notion of community and freedom, maintained that a social phenomenon has to be addressed on its own ontological plane (Durkheim, 1982 [1895]), sociologists and anthropologists are inclined to argue for the primacy of the social through evidence of subjects' defying their physical necessities to comply with their social norms, values, or even forces. Durkheim (2002 [1897]) himself exemplified his idea through his already classical example of altruistic suicide-the ultimate act of sacrificing one's own life for the benefit of the collectively. The bifurcation, however, evokes a tendency to undermine the potentiality of materiality in social life. Bodies are missing from social theories (Shilling, 2012), as theorists are occupied in explaining behaviour as the excess of social structure. Theorists who have attempted to incorporate the agency of technology have been considered technological determinists, in contrast to social constructivists (Bloor, 1999). Particularly in regard to how violence is theorized, the bifurcation has led to an inclination to dismiss violence as the reverberation of socially constructed morality or political circumstances (see Reemtsma, 2012).

\section{Conclusion}

The events of violence and the discursive boundary, bodily experiences and self-representation are, indeed, qualitatively different. Likewise, the discursively constructed identity cannot be reduced to an effect of the physicality of violence. However, what I ultimately suggest in this paper is that in order to attain a more adequate theoretical depiction of the cases presented here, we have to predicate 
the actuality of violence and the idea of identity as horizontally rather than hierarchically related (Bartmanski and Alexander, 2012). Just as language is not simply in opposition to the body's autonomic reception of an image (Massumi, 1995), the discursive boundary and the horrendous certainty of violence are co-constituting rather than opposed to each other. Therefore, this article invites studies of identity-related violence to broaden their theoretical imagination beyond the dichotomous notion of actuality and self-representation.

\section{References}

Ansori, M. H., Sukandar, R., Peranto, S., Karib, F., Cholid, S., \& Rasyid, I. (2014). Segregasi, Kekerasan, dan Kebijakan Rekonstruksi Pasca-Konflik di Ambon Jakarta: The Habibie Center.

Argenti, N., \& Schramm, K. (2010). Introduction: Remembering Violence: Anthropological Perspectives on Intergenerational Transmission. In N. Argenti \& K. Schramm (Eds.), Remembering Violence: Anthropological Perspectives on Intergenerational Transmission (pp. 1-39). New York: Bergahn Books.

Bakker, L. (2015). Illegality for the General Good? Vigilantism and Social Responsibility in Contemporary Indonesia. Critique of Anthropology, 35(1), pp. 78-93. doi:10.1177/0308275X14557092

Bartmanski, D., \& Alexander, J. C. (2012). Materiality and Meaning in Social LIfe: Toward an Iconic Turn in Cultural Sociology. In J. C. Alexander, D. Bartmanski \& B. Giesen (Eds.), Iconic Power: Materiality and Meaning in Social Life. New York: Palgrave Macmillan.

Bjorkhagen, M. (2013). The Conflict in the Moluccas: Local Youths' Perceptions Contrasted to Previous Research (Malmo University.

Bloch, M. (1992). Prey into Hunter: The Politics of Religious Experience Cambridge: Cambridge University Press.

Bloor, D. (1999). Anti-Latour. Studies in History and Philosophy of Science, 30(1), pp. 81-112.

Braithwaite, J. (2013). Maluku: Anomie to Reconciliation. In E. Aspinall, R. Jeffrey \& A. J. Regan (Eds.), Diminishing Conflicts in Asia and the Pacific: Why Some Subside and Others Don't (pp. 37-48). London: Routledge.

Bräuchler, B. (2004). Islamic Radicalism Online: The Moluccan Mission of the 
Laskar Jihad in Cyberspace. The Australian Journal of Anthropology, 15(3), pp. 267-285. doi:doi.org/10.1111/j.1835-9310.2004.tb00098.x

Cribb, R. (1990). Problems in the Historiography of the Killings in Indonesia. In R. Cribb (Ed.), The Indonesian Killings of 1965-1966 (pp. 1-43). Clayton: Centre of Southeast Asian Studies Monash University.

Cribb, R. (2001). Genocide in Indonesia, 1965-1966. Journal of Genocide Research, 3(2), pp. 219-239. doi:doi.org/10.1080/713677655

Deng, F. M. (1995). War of Visions: Conflict of Identities in the Sudan Washington, D.C.: Brookings Institution.

Duncan, C. R. (2014). Violence and Vengeance: Religious Conflict and its Aftermath in Eastern Indonesia Ithaca: Cornell University Press.

Durkheim, E. ((1895) 1982). Rules of Sociological Method (W. D. Halls, Trans.) New York: The Free Press.

Durkheim, E. ((1897) 2002). Suicide: A Study in Sociology (J. A. Spaulding \& G. Simpson, Trans.) London: Routledge.

George, K. (1996). Showing Signs of Violence: The Cultural Politics of a TwentiethCentury Headhunting Ritual Berkeley: University of California Press.

Girard, R. (1977). Violence and the Sacred (P. Gregory, Trans.) Baltimore: John Hopkins University Press.

Hartmann, E. (2017). Violence: Constructing an Emerging Field of Sociology. International Journal of Conflict and Violence, 11, pp. 1-9. doi:0.4119/ UNIBI/ijcv.623

Hasan, N. (2006). Laskar Jihad: Islam, Militancy, and the Quest for Identity in PostNew Order Indonesia Ithaca: Cornell Southeast Asia Program.

Hasworo, R. T. (2004). Penangkapan dan Pembunuhan di Jawa Tengah Setelah G-30-S. In J. Roosa, A. Ratih \& H. Farid (Eds.), Tahun yang Tak Pernah Berakhir: Memahami Pengalaman Korban 65 (pp. 25-59). Jakarta: Lembaga Studi dan Advokasi Masyarakat (Elsam).

Hearman, V. (2017). Contesting Victimhood in the Indonesian Anti-Communist Violence and Its Implications for Justice for the Victims of the 1968 South Blitar Trisula Operation in East Java. Journal of Genocide Research, 19(4), pp. 512-529. doi:doi.org/10.1080/14623528.2017.1393943

Henare, A., Holbraad, M., \& Wastell, S. (2007). Introduction: Thinking through Things. In A. Henare, M. Holbraad \& S. Wastell (Eds.), Thinking Through Things: Theorising Artefacts Ethnographically (pp. 1-31). London: Routledge. 
JR., W. H. S. (2005). Logics of History: Social Theory and Social Transformation Chicago: The University of Chicago Press.

Juergensmeyer, M. (2000). Terror in the Mind of God: The Global Rise of Religious Violence Berkeley: University of California Press.

Kapferer, B. (1988). Legends of People/Myths of State: Violence, Intolerance, and Political Culture in Sri Lanka and Australia Washington, D.C.: Smithsonian Institution Press.

Kivimaki, T. A. (2012). What Generates, Constitutes and Causes Opportunitydriven Violence? The Case of West Kalimantan. Asian Journal of Political Science, 20(3), pp. 284-303. doi: doi.org/10.1080/02185377.2012.748971

Klinken, G. v. (2007). Communal Violence and Democratization in Indonesia: Small Town Wars London: Routledge.

Levi-Strauss, C. (1969). The Elementary Structures of Kinship (J. H. Bell, J. R. VonSturmer \& R. Needham, Trans.) Boston: Beacon Press.

Liem, A. (2004). Perjuangan Bersenjata PKI di Blitar Selatan dan Operasi Trisula. In J. Roosa, A. Ratih \& H. Farid (Eds.), Tahun yang Tak Pernah Berakhir: Memahami Pengalaman Korban 65 (pp. 163-200). Jakarta: Lembaga Studi dan Advokasi Masyarakat (Elsam).

Ling, T. S. (2010). G30S 1965, Perang Dingin dan Kehancuran Nasionalisme: Pemikiran Cina Jelata Korban Orba Depok: Komunitas Bambu.

Maalouf, A. (2001). In the Name of Identity: Violence and the Need to Belong New York: Arcade Publishing.

Marion, J. L. (2010). Certitudes negatives Paris: Grasset.

Massumi, B. (1995). The Autonomy of Affect. Cultural Critique, 31, pp. 83-109.

McGregor, K. (2009). A Reassessment of the Significance of the 1948 Madiun Uprising to the Cold War in Indonesia. Kajian Malaysia, 27(1-2), pp. 85 119.

McVey, R. ((1965) 2006). The Rise of Indonesian Communism Singapore: Equinox Publishing.

Melvin, J. (2015). Documenting genocide. Retrieved Date from http://www. insideindonesia.org/documenting-genocide.

Melvin, J. (2017). Mechanics of Mass Murder: A Case for Understanding the Indonesian Killings as Genocide. Journal of Genocide Research, 19(4), pp. 487-511. doi:doi.org/10.1080/14623528.2017.1393942 
Miller, D. (2005). Materiality: An Introduction. In D. Miller (Ed.), Materiality (pp. 1-50). Durham: Duke University Press.

Peluso, N. L. (2006). Passing the Red Bowl: Creating Community Identity through Violence in West Kalimantan, 1967-1997. In C. A. Coppel (Ed.), Violent Conflicts in Indonesia: Analysis, Representation, Resolution (pp. 106128). London: Routledge.

Pirous, I. (2004). Constructing Iban Identity: The Narratives of Vanishing and Emerging within the Transnational Borderzone of Borneo Island (Master. Nottingham Trent University.

Qurtuby, S. A. (2015). Christianity and Militancy in Eastern Indonesia: Revisiting the Maluku Violence. Southeast Asian Studies, 4(2), pp. 313-339

Reemtsma, J. P. (2012). Trust and Violence: An Essay on a Modern Relationship Princeton and Oxford: Princeton University Press.

Riches, D. (1986). The Phenomenon of Violence. In D. Riches (Ed.), The Anthropology of Violence. New Jersey: Blackwell.

Robinson, G. (2017). "Down to the Very Roots": The Indonesian Army's Role in the Mass Killings of 1965-66. Journal of Genocide Research, 19(4), pp. 465-486. doi:doi.org/10.1080/14623528.2017.1393935

Rochijat, P. (1985). Am I PKI or Non-PKI? Indonesia, 40, pp. 37-56. doi:cip. cornell.edu/seap.indo/1107007217

Ross, M. H. (2002). Psychocultural Interpretations and Dramas: Identity Dynamics in Ethnic Conflict. Political Psychology, 22(1), pp. 157-178. doi:https://doi.org/10.1111/0162-895X.00231

Sahlins, M. (1972). Stone Age Economics Chicago: Aldine Atherton Inc.

Sahlins, M. (1985). Islands of History Chicago: The University of Chicago Press.

Sahlins, M. (1991). The Return of the Event, Again: With Reflections on the Beginnings of the Great Fijian War of 1843 to 1855 between Kingdoms of Bau and Rewa. In A. Biersack (Ed.), Clio in Oceania: Toward a Historical Anthropology. Washington, D.C.: Smithsonian Institution Press.

Scarry, E. (1985). The Body in Pain: The Making and Unmaking of the World New York: Oxford University Press.

Sen, A. (2008). Violence in Identity. In I. A. Karawan, W. McCormack \& S. E. Reynolds (Eds.), Values and Violence: Intangible Aspects of Terrorism (pp. 3-13). New York: Springer.

Shilling, C. (2012). The Body and Social Theory London: SAGE Publications. 
Where is the violence in identity-related violence? The generative potentiality of violence in ... (Geger Riyanto)

Staudigl, M. (2014). Introduction: Topics, Problems, and Potentials of a Phenomenological Analysis of Violence. In M. Staudigl (Ed.), Phenomenologies of Violence (pp. 1-32). Leiden: Brill.

Tambiah, S. J. (1997). Leveling Crowds: Ethnonationalist Conflicts and Collective Violence in South Asia Berkeley: University of California Press.

Volkan, V. (2006). Killing in the Name of Identity: A Study of Bloody Conflicts Charlottesville: Pitchstone Publishing.

Watch, H. R. (1999). Indonesia: The Violence in Ambon. https://www.hrw.org/ reports/1999/ambon/

Wellman JR., J. K., \& Tokuno, K. (2004). Is Religious Violence Inevitable? Journal for the Scientific Study of Religion, 43(3), pp. 291-296. doi:https:// doi.org/10.1111/j.1468-5906.2004.00234.x

Whitehead, N. (2004). On the Poetics of Violence. In N. Whitehead (Ed.), On the Poetics of Violence (pp. 55-78). Sante Fe: SAR Press.

Wilson, C. (2011). Ethno-Religious Violence in Indonesia: From Soil to God New York: Routledge.

Winn, P. (2000). Banda Burns. Retrieved Date from http://www. insideindonesia.org/banda-burns.

Young, K. R. (1990). Local and National Influences in the Violence of 1965. In R. Cribb (Ed.), The Indonesian Killings of 1965-1966 (pp. 63-99). Clayton: Centre of Southeast Asian Studies Monash University. 
Journal of Social Studies (JSS), Volume 16, Number 1, 2020: 83-102 